\title{
Effect of Diabetic Control on the Level of Circulating Thyroid Hormones
}

\author{
J.L. Schlienger ${ }^{1}$, A. Anceau ${ }^{1}$, G.Chabrier ${ }^{1}$, M. L. North ${ }^{2}$ and F. Stephan ${ }^{1}$ \\ ${ }^{1}$ Service d'Endocrinologie et des Maladies de la Nutrition, ${ }^{2}$ Centre de Transfusion Sanguine, Hôpital Civil, Strasbourg, France
}

\begin{abstract}
Summary. Basal plasma levels of thyroxine (T4), triiodothyronine (T3) and reverse T3 were determined by radioimmunoassay in 44 control subjects, 44 Type 1 (insulin-dependent) and 39 Type 2 (non insulin-dependent) diabetic patients aged from 15 to 75 years. All were clinically euthyroid. The quality of diabetic control was assessed by the percentage of glycosylated haemoglobin. In both the diabetic groups there was a significant decrease in T3 and a rise in reverse $\mathrm{T} 3$ whereas $\mathrm{T} 4$ was normal. We found no significant differences between plasma thyroid hormone levels in Type 1 and Type 2 diabetic patients. In the poorly controlled diabetics (glycosylated haemoglobin $\geqslant 12 \%$ ), T3 was $90 \pm 5 \mathrm{ng} / \mathrm{dl}$, which differed significantly from the level found in the better controlled patients $(106 \pm 5 \mathrm{ng} / \mathrm{dl}, p<0.01)$. In the diabetic patients without associated illness, a negative linear correlation was found between T3 and glycosylated haemoglobin and a positive correlation between reverse T3/T3 and glycosylated haemoglobin. No correlation between T3 or reverse T3 and fasting blood glucose could be established. In conclusion, many diabetics showed a low T3 syndrome suggesting that there may be an impairment in the extrathyroidal conversion of T4 to T3. This may well be enhanced by a poor diabetic control (glycosylated haemoglobin $\geqslant 12 \%$ ).
\end{abstract}

Key words: Type 1 and Type 2 diabetes, circulating thyroid hormones, glycosylated haemoglobin.

It is generally agreed that the plasma concentration of thyroid hormones is disturbed in untreated diabetes mellitus: triiodothyronine (T3) is low, reverse T3 has a tendency to rise whereas thyroxine (T4) remains with- in normal limits [1-3]. These values revert towards normal when efficient treatment achieves good metabolic control $[1,3]$. An impairment of the extra-thyroidal conversion of $\mathrm{T} 4$ to $\mathrm{T} 3$ and decreased catabolism of reverse $\mathrm{T} 3$, which are both regulated by the same $5^{\prime}$ monodeiodase, is the most likely explanation of these abnormalities $[4,5]$. A reduction in hepatic T4- $5^{\prime}$ monodeiodase activity has been reported recently in streptozotocin-induced diabetic rats [6] and a recovery of the enzyme activity was observed after insulin infusion. The aim of the present study was to investigate the possible relationship between thyroid hormone concentrations and the quality of diabetic control as assessed by the percentage of glycosylated haemoglobin.

\section{Patients and Methods}

Eighty-three diabetic patients ( 40 men and 43 women) not suffering from any associated illness were studied on the morning following hospital admission for periodic evaluation and/or adjustment of treatment. They were clinically euthyroid. Their mean glycosylated haemoglobin concentration was $12 \pm 0.4 \%$ of total haemoglobin. Among these patients 44 ( 25 men, 19 women) were Type 1 diabetic patients with a mean age of $36 \pm 4$ years (range 15-54 years) and 39 (15 men, 24 women) were Type 2 diabetic patients with a mean age of $59 \pm 3$ years (range 39-75 years). Ketoacidosis or simple ketosis was found in eight patient of the Type 1 diabetic group. We compared them with 44 non-diabetic patients ( 26 men, 18 women), showing no evidence of infections, renal, hepatic, metabolic or endocrine disease. Their mean age was $39 \pm 4$ years (range 17-59 years).

After an overnight fast, blood was drawn from an antecubital vein for determination of plasma $\mathrm{T} 4, \mathrm{~T} 3$, reverse $\mathrm{T} 3$ concentrations by radioimmunoassay (kits commercialized by Abbott Laboratory, Paris), fasting blood glucose by glucose oxidase and glycosylated haemoglobin by microchromatography according to Kynoch-Lehmann (upper limit of normal is $8 \%$ in our laboratory with an accuracy of $8.1 \%$ and an inter-assay reproducibility of $10 \%$ ). The free thyroxine index was determined by multiplying $\mathrm{T} 4$ by percentage of 
Table 1. Thyroid hormones in diabetes

\begin{tabular}{lllll}
\hline & $\begin{array}{l}\mathrm{T} 4 \\
(\mu \mathrm{g} / \mathrm{dl})\end{array}$ & $\begin{array}{l}\text { Free } \\
\text { thy- } \\
\text { roxine } \\
\text { index }\end{array}$ & $\begin{array}{l}\mathrm{T3} \\
(\mathrm{ng} / \mathrm{dl})\end{array}$ & $\begin{array}{l}\text { Reverse } \\
\mathrm{T} 3 \\
(\mathrm{ng} / \mathrm{dl})\end{array}$ \\
\hline $\begin{array}{c}\text { Control group } \\
(n=44)\end{array}$ & $7.7 \pm 0.3$ & $2.1 \pm 0.1$ & $144 \pm 3$ & $20.4 \pm 1.3$ \\
$\begin{array}{c}\text { All diabetic } \\
\text { patients } \\
(n=83)\end{array}$ & $7.7 \pm 0.4$ & $2.2 \pm 0.2$ & $108 \pm 5$ & $25.3 \pm 1.1$ \\
$\begin{array}{c}\text { Type 1 diabetic } \\
\text { patients } \\
(n=44)\end{array}$ & $7.6 \pm 0.3$ & $2.1 \pm 0.1$ & $110 \pm 5$ & $25.5 \pm 1.6$ \\
$\begin{array}{c}\text { Type 2 diabetic } \\
\text { patients } \\
(n=39)\end{array}$ & $7.8 \pm 0.5$ & $2.3 \pm 0.3$ & $103 \pm 6$ & $25.2 \pm 1.7$ \\
\hline $\begin{array}{l}\text { Ketotic Type 1 } \\
\text { diabetic } \\
\text { patients }(n=8)\end{array}$ & $7.6 \pm 0.3$ & $2.3 \pm 0.1$ & $124 \pm 14$ & $25.2 \pm 1.2$ \\
$\begin{array}{l}\text { Non-ketotic } \\
\text { Type 1 diabetic } \\
\text { patients } \\
(n=8)\end{array}$ & $7.8 \pm 0.5$ & $2.2 \pm 0.1$ & $115 \pm 6$ & $23.5 \pm 1.9$ \\
\hline
\end{tabular}

Results expressed as mean \pm SEM

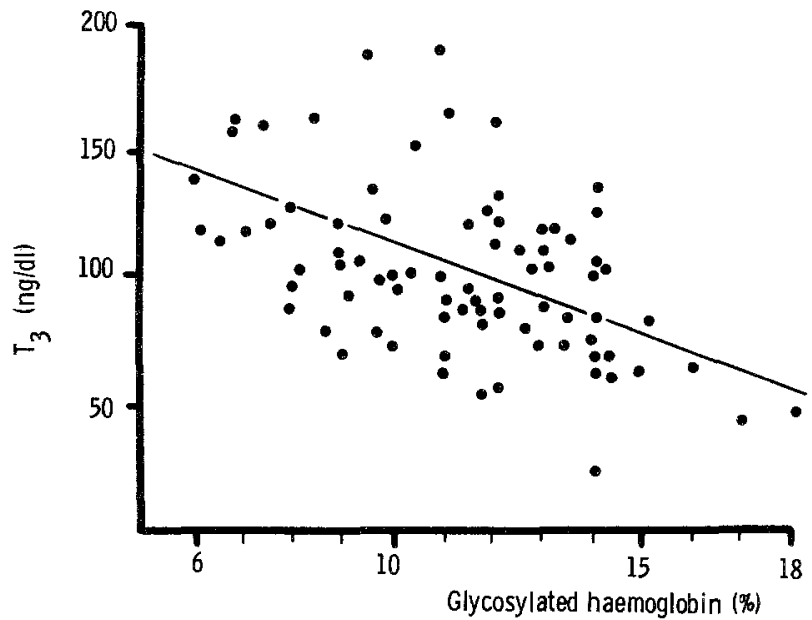

Fig. 1. Correlation between plasma $\mathrm{T} 3$ level and the percentage of glycosylated haemoglobin in diabetic patients without associated illness $(y=-4.27 x+155.77, r=-0.306, p<0.01)$

resin T3 uptake (Triosorb Abbott). All the results are expressed as mean \pm SEM. They were compared by Student's t-test for unpaired series. Correlations were determined by regression analysis.

\section{Results}

Type 1 or Type 2 diabetic patients had lower T3 concentrations $(p<0.01)$ and higher reverse T3 concentrations $(p<0.01)$ than normal subjects (Table 1). T4 concentration and free thyroxine index were the same in both groups. No difference in hormonal concentration between ketotic and non-ketotic Type 1 patients, sex and age matched, was found.

There was a negative correlation between $\mathrm{T} 3$ and age $(r=-0.49 ; p<0.001)$ in diabetic patients. In the poorly controlled diabetic patients, (glycosylated haemoglobin $\geqslant 12 \%$ ), the mean T3 level was significantly lower than in the better controlled patients (97 \pm 5 versus $117 \pm 5 \mathrm{ng} / \mathrm{dl}, p<0.05$ ). There was a negative correlation between $\mathrm{T} 3$ and glycosylated haemoglobin $(p<0.01$; Fig. 1$)$. However, the T3 levels did not correlate with fasting blood glucose levels determined in the same blood sample $(r=0.181$, NS). The mean plasma reverse T3 level found in the poorly controlled diabetic patients did not differ significantly from the values found in the better controlled patients $(27 \pm 2$ versus $23 \pm 2 \mathrm{ng} / \mathrm{dl}$, NS). No correlation was found between reverse T3 and glycosylated haemoglobin but the ratio reverse $\mathrm{T} 3 / \mathrm{T} 3$ correlated positively with glycosylated haemoglobin $(r=0.294, p<0.05)$. The plasma T4 concentration was normal in all patients and not influenced by age or by the quality of diabetic control.

\section{Discussion}

The mean plasma T3 concentration was low and reverse T3 was increased in the 83 diabetic patients investigated in this study. These results are consistent with those reported in the literature $[1,2]$ and are probably related to an impairment in $5^{\prime}$ monodeiodase which controls the conversion of $\mathrm{T} 4$ into $\mathrm{T} 3$ and the catabolism of reverse T3 $[3,6]$. However, unlike some observers, we could not find any correlation between these two metabolites of T4 in our patients [7].

In diabetes, different investigations showed that serum T3 levels may be strongly influenced by the quality of diabetic control and suggested a relationship between the decreased T3 production and impaired glucose utilization [1-3]. This is somewhat similar to the low plasma T3 levels observed by Spaulding et al. [8] and by Sims [9] in volunteers submitted to a reduced carbohydrate intake. The present data are consistent with these facts. They indicate that it may be long-term diabetic control that determines the plasma T3 levels because this hormone correlates negatively with glycosylated haemoglobin and not with fasting glycaemia. This concept agrees with the observations of Pittman et al. [2] showing that in five diabetic patients, the serum T3/T4 ratio increased but remained below the normal range after 10 days of dietary and insulin treatment. The long term hyperglycaemia seems to regulate the plasma T3 level but we 
could not demonstrate any effect on the production of reverse T3. In our patients the plasma reverse T3 levels were not significantly influenced by the percentage of glycosylated haemoglobin and no correlation between reverse T3 and glycosylated haemoglobin could be established. However, the ratio reverse T3/T3 correlated positively with glycosylated haemoglobin. In a recent paper, Gavin et al. [6] demonstrated that short-term hyperglycaemia reduced hepatic T4-5' deiodinase activity in the diabetic rats and a delayed recovery of this enzyme activity was observed after insulin administration. These data are in agreement with those found in diabetic men. Many other factors may affect the plasma concentration of $\mathrm{T} 3$ and $\mathrm{T} 4$ besides the quality of long-term diabetic control. It must be emphasized that a low T3 syndrome may occur in all diseases characterized by increased catabolism [5]. The influence of age on the thyroid hormone levels remains controversial [12]. However, we observed that in patients having a glycosylated haemoglobin $<12 \%$, old age ( $>60$ years) enhanced significantly the fall in plasma $\mathrm{T} 3$ and the rise in plasma reverse T3.

\section{References}

1. Saunders J, Hall SEH, Sönksen PH(1978) Thyroid hormones in insulin requiring diabetes before and after treatment. Diabetologia $15: 29-32$

2. Pittman CS, Suda AK, Chambers JB Jr, Ray GY (1979) Impaired $3,5,3^{\prime}$-triiodothyronine (T3) production in diabetic patients. Metabolism 28:333-338

3. Pittman CS, Suda AK, Chambers JB Jr, McDaniel HG, Ray GY, Preston BK (1979) Abnormalities of thyroid hormone turnover in patients with diabetes mellitus before and after insulin therapy. J Clin Endocrinol Metab 48:854-860

4. Balsam A, Ingbar SH (1978) The influence of fasting, diabetes and several pharmacological agents on the pathways of thyroxine metabolism in rat liver. J Clin Invest 62: 415-424

5. Utiger RD (1980) Decreased extrathyroidal triiodothyronine production in non-thyroidal illness: benefit or harm? Am J Med 69: 807-810

6. Gavin LA, McMahon FA, Moeller M (1981) The mechanism of impaired $\mathrm{T} 3$ production from $\mathrm{T} 4$ in diabetes. Diabetes 30 : 694-699

7. Cavalieri RR, Rapoport B (1977) Impaired peripheral conversion of thyroxine to triiodothyronine. Ann Rev Med 28: 57-65

8. Spaulding SW, Chopra IJ, Sherwin RS, Lyall SS (1976) Effect of caloric restriction and dietary composition on serum T3 and reverse T3 in man. J Clin Endocrinol Metab 42:197-200

9. Sims EAH (1976) Experimental obesity, dietary-induced thermogenesis and their clinical implications. Clin Endocrinol Metab 5: 377-395

10. Baldet L, Mendoza E, Selam JL, Pham TC, Jaffiol C, Mirouze J (1981) Changes in thyroid hormone levels during the treatment of ketotic diabetes. Horm Metab Res 13:236-237

11. Postellon DC, Becker DJ, Foley TP Jr (1978) Alterations in triiodothyronine (T3) and reverse triiodothyronine (rT3) concentrations in newly diagnosed patients with juvenile diabetes mellitus. Diabetes 27:498 (Abstract)

12. Olsen T, Laurberg P, Weeke J (1978) Low serum triiodothyronine and high serum reverse triiodothyronine in old age: an effect of disease not age. J Clin Endocrinol Metab 47: 1111-1115

Received: 27 May 1981

and in revised form: 15 February 1982

Professor F. Stephan

Pavillon Leriche

Hôpital Civil

67091 Strasbourg Cedex,

France 